УДК 769.1.041(98)

\title{
МИР ЧЕЛОВЕКА АРКТИКИ В ГРАФИКЕ МИХАИЛА СТАРОСТИНА
}

Борисова Айталина Андриановна

ФГБОУ ВО «Арктический государственный институт культуры и искусств»

\begin{abstract}
Аннотация: Статья посвящена рассмотрению творчества якутского художника Михаила Старостина, посвященного теме мировосприятия северного человека. Впервые исследованию подверглись его взгляды на характерные особенности сознания людей, живущих в суровых арктических условиях. Обращено внимание на выразительные средства, при помощи которых передан внутренний духовный мир этих людей.
\end{abstract}

Ключевые слова: Арктика, северный человек, мир, художник, творчество.

\section{THE WORLD OF HUMAN OF THE ARCTIC IN THE GRAPHICS OF MIKHAIL STAROSTIN}

\section{Borisova Aitalina Andrianovna}

Abstracts: The article is devoted to the analysis of the creativity of the Yakut artist Mikhail Starostin, dedicated to the theme of the world perception of a northern person. For the first time, his insights into the characteristics of the minds of people living in harsh Arctic conditions were studied. Attention is drawn to the expressive means by which the inner spiritual world of these people is transmitted.

Key words: Arctic, northern man, world, artist, creativity.

В современном мире перед малыми народами Севера остро стоят проблемы сохранения их традиционной культуры, особенно хрупкой и уязвимой в условиях модернизации и глобализации. Эта культура, хорошо приспособленная к суровым условиям Арктики, существующая в симбиозе с северной природой, и обладающая неповторимым обликом, привлекает внимание творческих людей, в том числе художников. В центре внимания находится образ северного человека неповторимого в своих проявлениях и являющегося неисчерпаемым источником вдохновения. 
Классики якутской живописи и графики А.Н. Осипов, Э.И. Васильев, Э.С. Сивцев, А.П. Мунхалов, В.С. Карамзин и др. неоднократно обращались в своем творчестве к теме Севера. Им были близки темы природы, трудового быта, культуры, истории малочисленных народов Севера Якутии. Характерный для них позитивизм вместе с тем сочетался с достоверностью и реалистичностью изображения. Основываясь на традициях российского изобразительного искусства, они передавали свое мироощущение.

Ощущение взаимосвязи северных народов с арктической природой стало центральной темой изобразительного искусства Якутии. Одновременно важное место занимает тенденция расширить и углубить проблему осознания историко-культурного своеобразия народов.

Оживление культурной жизни в нашей стране в связи с острой потребностью обращения к историческому прошлому, с его ярко выраженным национальным колоритом сопровождалось бурными переменами в экономической и политической жизни общества в 1990-е гг.

Художники, чей приход в искусство пришелся на этот период, предпринимали попытки поиска новых способов рефлексии реальности и ее живописного осмысления. Это нашло отражение в усилении концептуализма, который получил различные преломления в изобразительном искусстве Якутии [1, с. 16]. Основываясь на народных традициях и опыте предшественников и отказываясь от шаблонов соцреализма, художники все чаще стали применять методы символизма как способ выражения. Кроме того, на первый план выходит человек с его духовным миром.

К этому непростому переломному периоду относится становление творческой индивидуальности якутского художника, графика Михаила Старостина. Его творчество отличается этничностью, концептуальностью, знаково-символическим мышлением [2, с. 92]. В его центре - мир северного человека в сопряжении с современными реалиями.

Мир человека Арктики в творчестве Старостина основывается на историческом прошлом северных народов. Он обращается к этнографическим и историческим трудам. В свое время книга исследователя-этнографа В.Г. Тан-Богораза «Материальная культура чукчей» произвела на него большое впечатление и наложила отпечаток на его творчество и формирование индивидуального стиля.

М. Старостин создает собирательный образ человека Арктики, и мир, в котором он живет - условный и абстрактный. 
Его герои органичны и историчны, в них собраны устойчивые черты северного характера - самодостаточность, простота, близость к природе. Герои М.Старостина - часть пространства, которое вокруг них во многом условно. Данный эффект усиливается динамичностью его персонажей, которые находятся почти в пути или движении - в лодке, на быках, пешком («Охотники» (1994), «Дорога домой» (1997), «Ноша» (2001), «Поспешивший» (2005), «Охотник и ворон» (2005), «Ветер у подножия Сэттэ Дабаан» (2008), «Сезон дождей» (2009)) [3, с. 2].

Рыбаки, охотники, путники, персонажи его картин словно вышли из прошлого. Их прототипы он успел застать еще в своем детстве.

М.Старостин так делится впечатлениями о них: «Герой моих картин человек северный, стойкий, самодостаточный. Это, скорее, собирательный образ, чем какой-то конкретный человек. Своих героев я ставлю в разные придуманные мной современные ситуации, продолжаю северную тематику. Так, через этого человека Севера я раскрываю вечные темы Любви, Добра и Зла, смены времен года.

Литераторы, писатели, художники создают свой мир. Я тоже создаю свой мир. Персонажи моих картин - рыбаки, охотники, путники, - не наши современники, они из прошлого. Они мне очень симпатичны и в каждого из них вкладываю частичку себя. Искренне рад, что смог визуализировать для своих современников образ традиционного якутского, северного человека.

Я застал их еще в своем детстве, ведь мой дед занимался охотой, рыболовством. Они одеты в традиционную глухую одежду с капюшоном, кухлянку, на их ногах торбаса. Мне нравится изображать, прорисовывать их образ вплоть до всех мелочей, - рыболовные сети, подвешенные к поясу нож и сумочки с огнивом, вязанки хвороста, орудия труда и охоты, которые они всегда несут с собой, в некоторых работах у них есть тымтай - берестяные короба. Эта деталь - их отличительная особенность, ведь если человек на себе что-то несет, это означает, что ему есть, куда нести свою поклажу, что ему есть дело до всего мироустройства и он сопричастен этому миру.

Вообще, если рассуждать далее, можно шире рассказать тот мир, где живет мой человек, показать животных, природу. Но, честно говоря, мне немного сложно, ведь насколько я понимаю в Арктике - другая природа, не совсем та, которую я видел в детстве. Поэтому мне предстоит открыть, самому узнать этот арктический мир поближе и воплотить его в своих картинах» [4, с. 98-99]. 


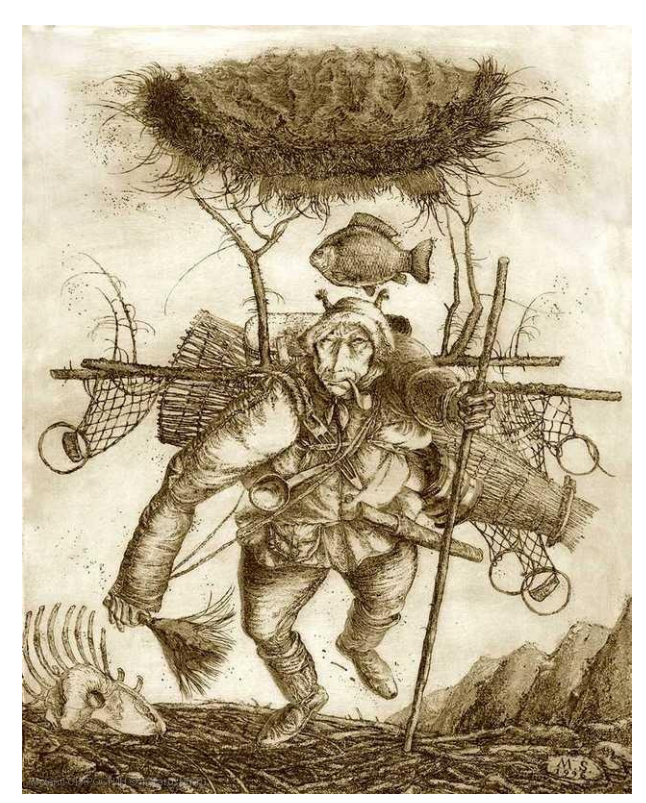

Рис. 1. Рыбак. 1996. Офорт. 32х25,5 cм

В офортном листе «Рыбак» (рис.1) изображен мужчина средних лет, который направляется на рыбалку. Первое, что бросается при взгляде на картину - это то, насколько велика поклажа, которую несет на себе этот человек. На его спине - берестяной короб (тымтай) и верша (морда), сплетенная из ивы и предназначенная для ловли рыбы, а также сети с множеством расположенных на них колец и грузилами. Поверх рыболовных снастей лежат тонкие деревца с растущими из них извилистыми сучьями, на самые тонкие концы которых взгромождено большое гнездо с торчащими из него прутиками, ошметками травы и которое кажется очень большим и основательным. В этом гнезде можно увидеть силуэты птенцов с широко открытыми клювами, очевидно эта символическое изображение семьи рыбака и хрупкости ее существования без еды. На груди мужчины висит большая ложка - которой он хочет есть, а на поясе - традиционный якутский нож, незаменимый при разделке добычи, и сумочки для мелочей. Человек, не смотря на большую поклажу, идет быстрым, легким, энергичным шагом. Изпод его ног вылетает мелкий хворост, властной, жилистой рукой он сжимает палку-посох. В другой руке он несет дэйбир - якутскую комаромахалку, которая делается из лошадиного волоса и позволяла отмахиваться ею от летнего гнуса. В то же время, дэйбир имеет значение защиты от напастей и злых духов и является одним из важных атрибутов рыбака, потому что прикреплена к кожаной перевязи, что висит у него на плече. Видно, что он дорожит ею и боится потерять. 
Его лицо - это лицо человека, который живет в нелегких условиях и привык к суровой действительности. Он знает, что жизнь не преподнесет ему подарков и легкой добычи, но он готов эту добычу найти и поймать сам, потому что на его плечах - груз большой семьи, которую он должен прокормить. Большая ложка выполняет роль символа потребности в насущном хлебе, постоянного двигателя и мотиватора его поступков и устремлений. Губы рыбака крепко сжимают деревянную трубку, а взгляд с легким прищуром погружен в сладостные мысли о большой рыбе, которую он должен поймать. Эта мечта визуализирована в виде большого якутского карася - он отличается особой жирностью и ценными вкусовыми качествами, потому что живет в холодных водах студеных арктических озер. И именно поимка этой рыбы даст рыбаку и его семье силы, чтобы выжить в условиях Арктики.

Человек оставляет за своей спиной горы, как символ препятствий, которые он преодолевает. Его дорога неровная, и рыбак попирает и отмахивает дэйбиром кости и лошадиный череп - символ смерти, который он отрицает своей волей к жизни и мечтой о большой рыбе, которую мы уверены он поймает, будучи таким решительным и целеустремленным.

Впечатляет тщательность и детализация картины, которых художник смог достигнуть при помощи графической техники офорта. На главного героя хочется смотреть, разглядывая каждую деталь и штрих одежды или утвари, что он с собой несет.

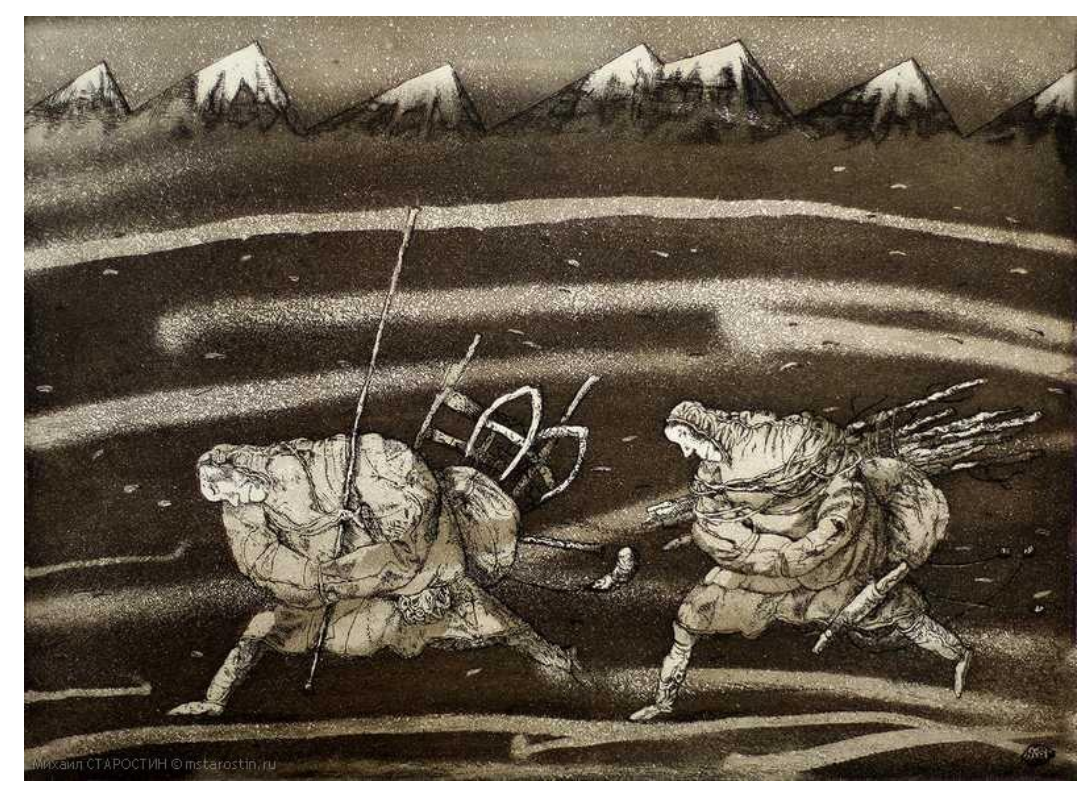

Рис. 2. Ветер у подножия Сэттэ Дабаан. 2008. Офорт, акватинта. $23 \times 29$ см 
Картина «Ветер у подножия Сэттэ Дабаан» (рис.2) выполнена в смешанной технике акватинты - особой разновидности офорта, который позволяет создавать разнообразный тоновый рисунок различных форм и фактуры. На листе изображены два путника, которые идут вперед, несмотря на сильно дующий ветер. Ветер изображен в форме широких белых полос, которые буквально накрывают людей и преграждают им путь. Насколько он сильный можно судить по сумочке с огнивом, которая еле удерживается от порывов ветра на тонком кожаном ремешке. Они вынуждены нагнуться и склонить свои головы, но они не сдаются и их лбы буквально «пробуравливают» это неуютное пространство. Насколько холодный и пронзительный ветер мы видим по тому, насколько плотно застегнута их верхняя одежда, а кисти рук тщательно спрятаны в рукава. Мелкие снежные частицы, крутящиеся и летающие вокруг кусочки льда пронзают все пространство полотна. Видно, что люди пробираются в этой пурге практически на ощупь, закрыв глаза. Они также несут с собой свою поклажу лыжи-снегоступы, легкие сани, вязанку хвороста для разжигания костра, без которых им просто не выжить в такой холод. Но вместе с тем шаг их широк, пружинист и упруг. Они практически легкой рысцой перекрывают пространство, наполненное беснованием северной стихии. Силу арктической природы, ее величественность и масштабность на картине воплощают семь заснеженных горных вершин, расположенных вверху композиции картины, у подножия которых свою дорогу жизни прокладывают путники Михаила Старостина.

Таким образом, художник воплощает мир человека Арктики, который складывается из двух составляющих - богатого внутреннего мира рыбаков, охотников с сильным характером, цельностью натуры, волей к жизни, устремленностью к победе над северной стихией, а также мира окружающего, внеличностного, объективного. Это та реальность, в которой живет герой картин Михаила Старостина. Эти два мира - внутренний и внешний, дополняют друг друга. Человек Арктики стал приспособленным к жизни благодаря тем условиям, в которых он живет, а мир Арктики был бы недостаточным без человека, который научился жить с ним в гармонии.

В картинах М. Старостина отражен уникальный, необъятный суровый и величественный мир северного человека в современном мире. Его образы условны, собирательны и тем самым универсальны. Картины художника не 
оставляют равнодушным зрителя, ведь при всей современности его творческого взгляда, он обращен вглубь веков - к человеку северному, человеку традиционному, который до сих пор еще живет в каждом из нас представителей коренных народов Якутии.

\section{Список литературы}

1. Луценко, Ю.В. Художественно-эстетическое самосознание художников Якутии на рубеже тысячелетий. Автореф... дис. кан. иск. - СПб.: 2009. -24 c.

2. Покатилова И.В. Острова Михаила Старостина / И. В. Покатилова // Ия Покатилова // Полярная звезда. - 2009. - № 2. - С. 92-96.

3. Неустроева Г.Г. Михаил Старостин. Живопись. Графика [Текст] / Г.Г. Неустроева. - Якутск, 2002. - С.1-2.

4. Борисова, А.А. Человек Севера - это интересно // Айар Кут. - 2019. №3. - C.94-105.

(C) А.А. Борисова, 2020. 